\title{
RANDOM WALKS AND MARKET EFFICIENCY: EVIDENCE FROM REAL ESTATE INVESTMENT TRUSTS (REIT) SUBSECTORS
}

\author{
Fahad ALMUDHAF ${ }^{1, *}$, Andrew J. HANSZ ${ }^{2}$ \\ ${ }^{1}$ Department of Finance and Financial Institutions, Kuwait University, P.O. Box 5486 Safat, 13055 Kuwait \\ 2 Department of Finance, Strome College of Business, Old Dominion University, Norfolk, VA 23529, USA
}

Received 4 July 2016; accepted 22 May 2017

\begin{abstract}
This paper investigates the random walk behavior of real estate investment trust (REIT) subsectors using monthly return data from January 1994 to July 2015. Using variance ratio tests, we examine subsectors of lodging/resorts and self-storage and find that they do not follow a random walk, contradicting the weak-form efficient market hypothesis. Nonparametric runs tests help us find that office, industrial, mixed, free standing, shopping centers, apartments, manufactured homes, and timberland subsectors are weak-form efficient. The evidence in this study supports the idea that some subsectors are more informationally efficient than other subsectors.
\end{abstract}

Keywords: random walk, market efficiency, Real estate investment trust (REIT) subsectors, variance ratio, Runs test.

\section{Introduction}

Real estate investment trust (REIT) subsectors ${ }^{1}$ have different characteristics, risks, cycles and behaviors and should therefore be independently evaluated. While lodging/resort REITs are viewed as aggressive investments with cyclical and volatile room and occupancy rates, healthcare, manufactured housing and self-storage REITs are considered somewhat recession resistant (Block, 2012). Bianchi, Guidolin, and Ravazollo (2013) indicates that there are different risk factors across residential and non-residential (office, industrial and retail) REITs. Property sectors differ in their price dynamics (Oikarinen, Hoesli, \& Serrano, 2010; Yavas \& Yildirim, 2011). Using sector level real estate data, Hoesli and Oikarinen (2012) show that REITs are strongly related to direct real estate in the long term.

It is expected that REIT subsectors follow their underlying real estate markets and therefore behave differently; so, this study investigates market efficiency of the main subsectors of the REIT market. REIT subsectors are diverse and heterogeneous while they differ in terms of their dividend yields, number of constituents and market capitalization ${ }^{2}$. Self-storage REIT is one of the smallest subsectors based on constituents count.

\footnotetext{
1 https://www.reit.com/investing/reit-basics/reit-sectors

2 https://www.reit.com/sites/default/files/returns/prop.pdf
}

Since the performance of REIT subsectors differ from year to year, active investors often overweight or underweight certain subsectors based on their views of risk and valuations. For example, self-storage was the best performing subsector in 2008, 2011 and 2015 while lodging/resorts was the best performing subsector in 2009 and 2013. On the other hand, self-storage was the worst performing subsector in 2009 and 2016 while lodging/resorts was the worst performing subsector in 2011 and $2015 .{ }^{3}$ Drivers of the subsectors performance are different which logically causes divergence in their performance. For instance, when economic growth is accelerating, subsectors such as office and lodging are expected to benefit from higher occupancy rate and an increase in demand. Residential REITs could benefit from an increase in the cost of debt (an interest rate hike) because this could decrease home ownership and therefore provide additional opportunity to rental markets. During recession, consumers spend less on non-necessities and therefore the lodging/resort subsector is negatively affected due to its short-term lease nature. On the other hand, demand for self-storage increases during such recession times since people downsize to smaller houses and younger individuals could move back to stay

3 http://alpinefunds.com/905998.pdf

*Corresponding author. E-mail: fmudhaf@cba.edu.kw 
with their families. Therefore, self-storage could benefit in such circumstances. Healthcare REITs are less sensitive to the economic environment (non-cyclical) while office, industrial and retail REITs are more economically sensitive with macroeconomic factors such as unemployment, interest rates and GDP growth.

The aim of this study is to investigate if there are differences in the informational efficiency of different REIT subsectors. The random walk implies that returns are not predictable. Since new information relative to REITs arrives randomly, we expect the market to react and reflect such information when pricing REITs. Consistent with the efficient market hypothesis, the random walk assumes that there are independent successive price changes in the market. Thus, we test separately for the efficiency of REIT subsectors. Moreover, we test if we can exploit such inefficiencies to generate abnormal profits using technical moving average rules. Both academic scholars and market practitioners are interested in market efficiency and in understanding the behavior of REIT returns. Academic scholars work to identify pricing behaviors and patterns in REITs, while practitioners seek to develop trading strategies based on market inefficiencies and asset mispricing.

This study contributes to existing literature in several ways. Firstly, this study is the first to provide new empirical evidence on the efficiency and random walk behavior of REIT subsectors. Secondly, this study uses recent data extending to July 2015 to test the random walk hypothesis of the REIT subsectors - market efficiency of REITs could be affected by the global financial crisis and this data covers the most recent economic recession, coined the Great Recession, and the post-crisis periods. Finally, this study complements and logically extends the work of Kleiman, Payne, and Sahu (2002) and Jirasakuldech and Knight (2005) as well as other articles that investigated the market efficiency of equity REITs.

Using monthly return data from January 1994 to July 2015 , this study employs variance ratio tests of Lo and MacKinlay (1988) and Wright (2000) as well as runs tests to examine the random walk hypothesis in REIT subsectors. Results indicate that the office, industrial, mixed, free standing, apartments, manufactured homes, and timberland subsectors are regarded as weak form efficient. Future returns in these subsectors are not related to the past or the current prices reflected in all public information. As a result, traders are not able to use technical analysis or historical prices to predict future returns and achieve abnormal profits. However, by using non-parametric runs tests, this study suggests strong evidence exists rejecting the random walk hypothesis of lodging/resorts and selfstorage indicating that it may be possible for technical traders to forecast these REIT subsector returns to earn excess profits. In addition, we examine the long-range dependence through fractional integration. There is strong evidence of long-memory in subsectors of industrial, mixed, shopping centers, free standing, apartments, diversified, healthcare and self-storage where shocks persist over long time periods.
Our results have some practical implications. Since some subsectors are more informationally efficient relative to other subsectors, traders could concentrate on such less efficient subsectors with better opportunities for abnormal returns. Also, this would imply that there are diversification benefits in using different REIT subsectors for asset al.ocation. The findings suggest that using aggregate REIT data may hide valuable subsector specific information and thus diminish the observed conclusions which are usually generalized for the overall REIT market. Moreover, researchers and portfolio managers should differentiate amongst property types since they have different risk-return characteristics.

\section{Literature review}

Several studies have examined whether REITs follow a random walk, including Kleiman et al. (2002), Lee and Chiang (2004), Jirasakuldech and Knight (2005), Schindler, Rottke, and Fuss (2010), Schindler (2011), Su, Cheung, and Roca (2012), and Aguilar, Boudry, and Connolly (2015). The empirical results of these studies are mixed. Variation in findings is due to the testing of different time periods, with different frequency (daily and monthly), and different methodologies. For instance, Kleiman et al. (2002) used unit root tests and variance ratio tests and found that international real estate markets in Asia, Europe and North America exhibit random walk behavior. Similarly, Lee and Chiang (2004) examined variance ratio tests with lags from one and 16 months and found that the stochastic pricing process of the equity REIT index follows a random walk. Likewise, Jirasakuldech and Knight (2005) shows that the efficiency of equity REITs increases over time.

In contrast, Kuhle and Alvayay (2000) document that $75 \%$ of nearly 50 equity REITs do not follow a random walk and are weak-form inefficient. Also, Mei and Gao (1995) rejects the random walk hypothesis and shows persistence in United States' (US) REIT markets coinciding with the results of Stevenson (2002) which used variance ratio for 11 countries and reported mean reversion. Studying calendar anomalies in twenty seven real estate markets, Hui, Wright, and Yam (2014) show statistical significance through linear regression is not sufficient to conclude that markets are not informationally efficient. They apply White reality check and Hansen superior predictability test to conclude that results are not economically significant. Thus, they interpret this as evidence supporting market efficiency.

Using wild bootstrap autocorrelation tests, Su et al. (2012) examined 14 international real estate markets. The results showed that only six of the 14 markets examined, including the United States, were efficient; however, the degree of efficiency varied considerably over time. This echoes the findings from Zhou and Lee (2013) who provide evidence that efficiency in REITs is time-varying which supports the Adaptive Market Hypothesis. Hui and Yam (2014) apply Shiryaev-Zhou index and show that traders can use it to better predict the market. Their find- 
ings show that this strategy beats the buy and hold rule. In a challenge to the efficient market hypothesis, M. T. Lee, M. L. Lee, Chiu, and C. L. Lee (2014) show that there is a significant new-moon effect anomaly in US REITs. They find that investors can generate profits if they buy REITs in the beginning of a new-moon period and then sell at the end of the period. Using binomial option pricing, Ho and Tay (2016) find that a number of Singapore REITs show strong pricing efficiency. Investigating long memory with structural breaks, Assaf (2015) finds that there is a break in REIT data during the economic crises of 2008. Also, there is weak evidence of long memory in REIT returns. This is consistent with earlier findings from Cotter and Stevenson (2008) who document long memory in volatility of REITs more than that of returns. This is also along the same line of the findings from Liow (2009) that show that there exists long memory in volatility in a number of international property markets.

Recently, Aguilar et al. (2015) applied variance ratio analysis to every US REIT listed from 1993 to 2011. The results indicated that REITs were generally efficient during this time period. More recently, Akinsomi, Aye, Babalos, Economou, and Gupta (2016) show that economic, monetary and sentiment indicators help in better predicting REIT returns.

The varying results of the above studies may stem from their differences in data frequency, differing time periods, changing methodologies, or the different countries they covered. Most of the above-mentioned studies focused on individual REITs or overall equity REIT indices and not on specific categories or subsectors, so, it is worth developing literature regarding the market efficiency of REIT subsectors.

Another strand of the literature investigates short term continuation of previous price movements (momentum) in REITs. For example, Chui, Titman, and Wei (2003) show that there is strong and profitable momentum effects in REITs during the period 1990-1999. This evidence casts doubt to the efficiency of REITs since prior information can be used to generate abnormal profits. This is consistent with Hung and Glascock (2008) who reconfirm significant momentum in REITs especially during bullish (up) markets. Similarly, Goebel, Harrison, Mercer, and Whitby (2013) show that there is momentum in REITs during the period 1993-2009. Moreover, Feng, Price, and Sirmans (2014) documents momentum in REIT subsectors of apartment, industrial, office and retail. Recently, Hao, Chu, Ko, and Lin (2016) find that the 52-week high momentum strategy is profitable when applied to REITs especially after optimistic periods with high investor sentiment. Thus, momentum seems to be a robust anomaly to the market efficiency of REITs.

Few studies directly address the varying efficiencies of REIT subsectors. Efficiency differences may stem from liquidity, the number of constituents being examined, market capitalization, and/or other risks. Payne (2006) found that REIT subsectors are not co-integrated which indicates market efficiency. In addition, Payne and Waters
(2007) show that bubbles may be detected in only particular REIT subsectors. More recently, using GARCH-DCC, Chong, Krystalogianni, and Stevenson (2012) showed an upward trend in the correlation between REIT subsectors from 1990 to 2008. By using current data that covers the most recent financial crisis and the post financial crisis, our study fills the gap in the literature and builds upon existing studies.

\section{Data and method}

Employing monthly REIT subsector indices from January 1994 to July 2015, this study applies conventional methods of the variance ratio from Lo and Mackinlay (1988, 1989 ) and the modified non-parametric signs and ranks based variance ratio tests from Wright (2000) to test the random walk hypothesis on REIT subsectors. The data set is sourced from the National Association of Real Estate Investment Trusts (NAREIT). Data for subsectors of mixed, timber, and infrastructure are only available starting from January 1996, 2011, and 2012, respectively. See Figure 1 below. There are several reasons which could be behind differences in the performance of REIT subsectors. This could be due to idiosyncratic (company-specific) especially in the sectors where the number of constituents is small (e.g self-storage). Also, it could be caused by differences in using leverage which certainly affects performance. Furthermore, average length of leases (e.g. lodging have short periods while office and industrial tend to have long-term leases).

The data provided by the statistical tests are complemented by the technical analysis of applying moving averages (3, 6, 9 and 12 months) to trading rules. Then, the returns of the naïve buy-and-hold strategy are compared with those of the technical model.

We use the variance ratio tests of Lo and MacKinlay (1988) which compares variances of returns in different intervals. The data follows a random walk whenever the variance of a $\mathrm{k}$-period difference is $\mathrm{k}$ times the variance of one period difference. The variance ratio is calculated as follows:

$$
V R(K)=\frac{\sigma_{k}^{2}}{\sigma_{1}^{2}},
$$

where: $\sigma_{k}^{2}$ is an unbiased estimator of $1 / \mathrm{k}$ of the kth term for the stock return series, and $\sigma_{1}^{2}$ is an unbiased variance of the first difference.

Under the hypothesis of homoscedasticity, the standard Z-test statistic is calculated as:

$$
\begin{gathered}
Z(K)=\frac{V R(k)-1}{[\varnothing(K)]^{1 / 2}} \sim N(0,1), \\
\text { where: } \varnothing(k)=\frac{[2(2 k-1)(k-1)]}{[3 k T]} .
\end{gathered}
$$

On the other hand, under the hypothesis of heteroscedasticity, the Z-statistic is calculated using: 

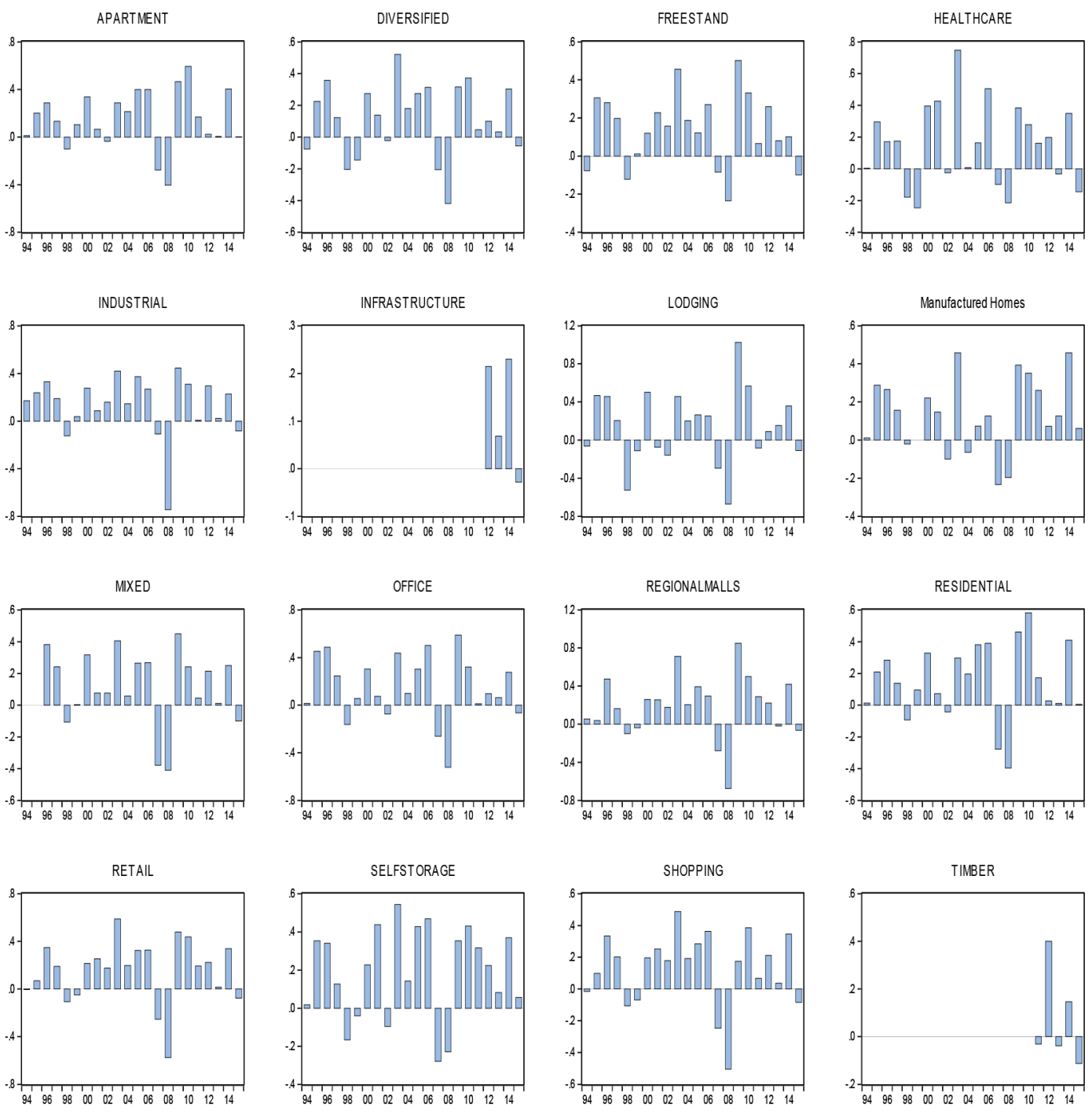

Figure 1. Annual returns of REIT subsectors

$$
Z^{*}(k)=\frac{V R(k)-1}{\left[\varnothing^{*}(K)\right]^{1 / 2}} \sim N(0,1),
$$

where: $\varnothing^{*}(k)=\sum_{j=1}^{k-1}\left[\frac{2(k-j)^{2}}{k}\right] \tau(j)$

with

$$
\tau(j)=\frac{\sum_{t=j+1}^{T K}\left(p_{t}-p_{t-1}-\mu\right)^{2}\left(p_{t}-p_{t-j-1}-\mu\right)^{2}}{\left[\sum_{k=1}^{T K}\left(p_{t}-p_{t-1}-\mu\right)^{2}\right]^{2}} .
$$

Prices follow a random walk as long as the variance ratio (VR) is one for $\mathrm{k}$ intervals. Returns are positively (negatively) correlated if VR is greater than (less than) one.

\section{Results}

Initially, an estimate is created for the autocorrelations of monthly REIT subsectors as shown in Table 1 . If the REIT subsectors are weakly efficient, then autocorrelation coefficients will not be significant and returns will not be time dependent. However, as indicated in Table 1, significant autocorrelations of multiple orders are observed in most subsectors (i.e. office, industrial, mixed, shopping centers, regional malls, apartments, manufactured homes, diversified, healthcare and lodging/resort). These results indicate a linear dependence for the returns of the REIT subsectors - evidence against market efficiency. This is similar to the findings in Jirasakuldech and Knight (2005) on equity REITs. Also, Schindler (2011) provides evidence of significant autocorrelation in US REITs using monthly GPR index returns with lags of up to 12 months. For all lag orders, the autocorrelation coefficients are statistically insignificant for free standing, self-storage, timberland and infrastructure REIT subsectors. This can be viewed as initial evidence supporting the view that these REIT subsectors have successive returns that independently follow a random walk. Significant positive autocorrelation coefficients can be interpreted as an indication of mean aversion. 
Table 1. Autocorrelation of monthly NAREIT subsector index returns

\begin{tabular}{|c|c|c|c|c|c|c|}
\hline & $\mathrm{ACF}_{1}$ & $\mathrm{ACF}_{2}$ & $\mathrm{ACF}_{3}$ & $\mathrm{ACF}_{6}$ & $\mathrm{ACF}_{12}$ & $\mathrm{ACF}_{24}$ \\
\hline Office & 0.0778 & -0.0976 & $0.1623^{\star * *}$ & $-0.2363^{\star * *}$ & $0.1479^{\star *}$ & -0.0769 \\
\hline Industrial & 0.0458 & $-0.2409^{* * *}$ & $0.2545^{\star \star \star}$ & $-0.1622^{\star \star \star}$ & 0.0545 & -0.0757 \\
\hline Mixed & 0.0361 & $-0.1712^{\star \star \star}$ & $0.1342^{\star \star}$ & $-0.2390^{\star \star \star}$ & $0.1971^{\star * *}$ & -0.0087 \\
\hline Shopping centers & 0.0555 & $-0.2311^{\star * \star}$ & 0.1083 & $-0.1844^{\star \star \star}$ & $0.1407^{\star \star}$ & 0.0058 \\
\hline Regional malls & $0.1460^{\star *}$ & -0.0547 & $0.1239^{\star \star}$ & $-0.2051^{\star \star \star}$ & 0.0864 & -0.0825 \\
\hline Free standing & -0.0533 & -0.1159 & 0.0278 & -0.0943 & 0.1152 & 0.0218 \\
\hline Apartments & 0.0145 & -0.0896 & 0.1157 & $-0.2044^{\star \star \star}$ & $0.1565^{\star \star}$ & -0.0472 \\
\hline Manufactured homes & -0.0349 & $-0.1830^{\star * \star}$ & 0.0866 & -0.0045 & $0.1442^{\star *}$ & 0.0514 \\
\hline Diversified & 0.1170 & $-0.2103^{* * *}$ & $0.1550^{\star *}$ & $-0.2362^{\star * *}$ & $0.1710^{* * *}$ & -0.0526 \\
\hline Healthcare & -0.0079 & $-0.1246^{\star *}$ & $0.1347^{\star *}$ & $-.1356^{\star *}$ & 0.0205 & 0.0287 \\
\hline Lodging/resort & $0.2054^{* * *}$ & $-0.1381^{\star *}$ & 0.1009 & $-0.1957^{\star * *}$ & $0.1494^{\star *}$ & -0.1010 \\
\hline Self-storage & -0.0588 & -0.0964 & 0.0659 & -0.0505 & 0.0590 & -0.0201 \\
\hline Timberland & -0.0678 & 0.2259 & -0.0617 & -0.0485 & -0.0100 & 0.0572 \\
\hline Infrastructure & -0.1679 & -0.0707 & 0.1309 & 0.2565 & -0.1241 & -0.0487 \\
\hline
\end{tabular}

${ }^{* *},{ }^{* *}$ denotes significance of the autocorrelation coefficients $\mathrm{ACF}_{\mathrm{k}}$ for lag $\mathrm{k}$ at $5 \%$, and $1 \%$ level respectively.

Table 2 displays the results of the non-parametric runs tests. These results show that office, industrial, mixed, shopping centers, free standing, apartments, manufactured homes, self-storage, and timberland subsectors are weak-form efficient. This is consistent with the results of Jirasakuldech and Knight (2005) which found that equity REITs, as an investment category, have become more efficient over time. Similarly, Lee and Chiang (2004) found that the equity REIT index of NAREIT follows a random walk. Further, Kleiman, Payne, and Sahu (2002) reported similar weak-form market efficiency in real estate markets. However, the null hypothesis of randomness is rejected for

Table 2. Non parametric runs test results

\begin{tabular}{|l|c|c|c|c|}
\hline & $\mathrm{M}$ & $\mathrm{E}(\mathrm{M})$ & $\sigma(\mathrm{M})$ & $\mathrm{Z}$ \\
\hline Office & 123 & 130.5 & 8.031 & -0.934 \\
\hline Industrial & 117 & 130.5 & 8.031 & -1.681 \\
\hline Mixed & 121 & 118.5 & 7.649 & 0.327 \\
\hline Shopping centers & 111 & 130.5 & 8.031 & $-2.428^{\star *}$ \\
\hline Regional malls & 121 & 130.5 & 8.031 & -1.183 \\
\hline Free standing & 121 & 130.5 & 8.031 & -1.183 \\
\hline Apartments & 135 & 130.5 & 8.031 & 0.560 \\
\hline Manufactured homes & 125 & 130.5 & 8.031 & -0.685 \\
\hline Diversified & 113 & 130.5 & 8.031 & $-2.1799^{\star *}$ \\
\hline Healthcare & 113 & 130.5 & 8.031 & $-2.1799^{* *}$ \\
\hline Lodging/resort & 113 & 130.5 & 8.031 & $-2.1799^{* *}$ \\
\hline Self-storage & 125 & 130.5 & 8.031 & -0.685 \\
\hline Timberland & 26 & 28.5 & 3.674 & -0.680 \\
\hline Infrastructure & 29 & 22.5 & 3.240 & $2.006^{* *}$ \\
\hline
\end{tabular}

$\mathrm{M}$ is the actual number of runs, $\mathrm{E}(\mathrm{M})$ is the expected number of runs, $\sigma(\mathrm{M})$ is the standard errors of runs, ${ }^{* *}$ indicates significance at the $5 \%$ level. shopping centers, diversified, healthcare, lodging/resorts, and infrastructure subsectors at the 5\% significance level as shown in Table 2. This indicates that these subsectors violate weak-form efficiency and exhibit some form of persistence. This also shows that the returns of these subsectors do not follow a random walk.

Table 3 shows the results of LM variance ratio tests (Lo \& MacKinlay, 1988) for the logarithm of each month, where $\mathrm{k}=2,4,8$, and 16 , with the assumption that standard error estimates with homoscedasticity, Z(k), are significant for the industrial, lodging/resorts, and self-storage subsectors. This means the null hypothesis of random walk in these subsectors is rejected. However, the random walk assumption is only violated in lodging and self-storage with a lag of 2 months under the assumption that standard error estimates exhibit heteroskedasticity, $Z^{\star}(\mathrm{k})$. In addition, Table 3 reports the results of the sign and rank based variance ratio tests $\left(R_{1}, R_{2}\right.$, and $\left.S_{1}\right)$ from Wright (2000). Using $R_{1}, R_{2}$, and $S_{1}$ the null hypothesis of a random walk is rejected for shopping centers, healthcare and lodging/ resorts. On the other hand, the null hypothesis for office, mixed, free standing, apartments, manufactured homes, diversified, timberland, and infrastructure is rejected using $\mathrm{R}_{1}$ and $\mathrm{R}_{2}$.

Results in Table 2 and 3 fail to reject the null hypothesis of a random walk for the subsectors of office, mixed, free standing, apartments, manufactured homes, and timber. This coincides with the findings of Kleiman, Payne, and Sahu (2002), Lee and Chiang (2004) and Jirasakuldech and Knight (2005). This study supports the view that some subsectors are more informationally efficient than other subsectors.

Why would a particular sector be more efficient when compared to others as indicated by the violation of the random walk in certain subsectors? Differences could be due to several reasons. First, subsectors differ in terms 
Table 3. Variance ratio statistics

\begin{tabular}{|c|c|c|c|c|c|c|c|}
\hline \multirow{2}{*}{ Subsector } & \multirow[b]{2}{*}{$\mathrm{k}$} & \multicolumn{3}{|c|}{ Lo and MacKinlay } & \multicolumn{3}{|c|}{ Wright } \\
\hline & & VR (k) & $\mathrm{Z}(\mathrm{k})$ & $\mathrm{Z}^{\star}(\mathrm{k})$ & $\mathrm{R}_{1}$ & $\mathrm{R}_{2}$ & $\mathrm{~S}_{1}$ \\
\hline \multirow[t]{4}{*}{ Office } & 2 & 1.065 & 1.053 & 0.504 & -1.191 & -1.041 & 0.808 \\
\hline & 4 & 1.088 & 0.753 & 0.397 & -0.617 & -0.770 & 1.760 \\
\hline & 8 & 1.196 & 1.068 & 0.609 & -0.300 & -0.367 & 3.214 \\
\hline & 16 & 1.203 & 0.741 & 0.459 & 0.194 & -0.072 & $4.951^{* *}$ \\
\hline \multirow[t]{4}{*}{ Industrial } & 2 & 1.125 & $2.015^{\star *}$ & 0.860 & 0.344 & 0.537 & 1.553 \\
\hline & 4 & 1.194 & 1.668 & 0.706 & 0.138 & 0.092 & 1.893 \\
\hline & 8 & 1.405 & $2.202^{* *}$ & 0.983 & 0.083 & -0.228 & 2.615 \\
\hline & 16 & 1.659 & $2.409^{* *}$ & 1.212 & 1.047 & 0.473 & $4.006^{* *}$ \\
\hline \multirow[t]{4}{*}{ Mixed } & 2 & 1.028 & 0.432 & 0.270 & -1.039 & -0.857 & -0.457 \\
\hline & 4 & 0.996 & -0.033 & -0.023 & -0.866 & -0.944 & 0.453 \\
\hline & 8 & 0.961 & -0.202 & -0.144 & -1.143 & -1.225 & 0.937 \\
\hline & 16 & 0.922 & -0.272 & -0.201 & -0.679 & -0.978 & 1.856 \\
\hline \multirow[t]{4}{*}{ Shopping centers } & 2 & 1.029 & 0.474 & 0.234 & 0.332 & -0.321 & 2.299 \\
\hline & 4 & 0.927 & -0.632 & -0.330 & 0.403 & -0.826 & $3.587^{\star *}$ \\
\hline & 8 & 1.023 & 0.125 & 0.068 & 0.882 & -0.403 & $5.125^{* * *}$ \\
\hline & 16 & 1.188 & 0.687 & 0.402 & $2.025^{\star *}$ & 0.600 & $7.016^{\star * *}$ \\
\hline \multirow[t]{4}{*}{ Regional malls } & 2 & 1.097 & 1.558 & 0.791 & 0.060 & 0.011 & 1.056 \\
\hline & 4 & 1.210 & 1.808 & 1.043 & 0.964 & 0.582 & 2.391 \\
\hline & 8 & 1.341 & 1.853 & 1.160 & 1.842 & 1.065 & 3.981 \\
\hline & 16 & 1.553 & $2.021^{* *}$ & 1.356 & $3.001^{\star * *}$ & 1.839 & 6.169 \\
\hline \multirow[t]{4}{*}{ Free standing } & 2 & 0.933 & -1.081 & -0.584 & -0.073 & -0.546 & 1.056 \\
\hline & 4 & 0.821 & -1.543 & -0.860 & -0.582 & -1.194 & 1.295 \\
\hline & 8 & 0.606 & $-2.141^{\star *}$ & -1.220 & -0.121 & -1.121 & 2.825 \\
\hline & 16 & 0.642 & -1.311 & -0.787 & 0.884 & -0.155 & 4.658 \\
\hline \multirow[t]{4}{*}{ Apartments } & 2 & 0.877 & $-1.974^{\star *}$ & -1.207 & -1.531 & $-2.019^{\star *}$ & -0.684 \\
\hline & 4 & 0.901 & -0.855 & -0.569 & -0.322 & -0.795 & 0.531 \\
\hline & 8 & 1.080 & 0.436 & 0.295 & 1.266 & 0.688 & 1.985 \\
\hline & 16 & 1.260 & 0.951 & 0.676 & $2.097^{* *}$ & 1.398 & 2.915 \\
\hline \multirow{4}{*}{$\begin{array}{l}\text { Manufactured } \\
\text { homes }\end{array}$} & 2 & 0.883 & -1.883 & -1.302 & -0.643 & -0.958 & 0.559 \\
\hline & 4 & 0.856 & -1.236 & -0.867 & -0.455 & -0.768 & 1.196 \\
\hline & 8 & 0.907 & -0.508 & -0.350 & -0.180 & -0.462 & 1.491 \\
\hline & 16 & 1.005 & 0.018 & 0.013 & 0.416 & 0.122 & 2.167 \\
\hline \multirow[t]{4}{*}{ Diversified } & 2 & 1.063 & 1.017 & 0.554 & 0.155 & -0.133 & 2.051 \\
\hline & 4 & 1.026 & 0.225 & 0.129 & 0.040 & -0.537 & 2.591 \\
\hline & 8 & 1.131 & 0.711 & 0.410 & 0.382 & -0.165 & 3.634 \\
\hline & 16 & 1.201 & 0.733 & 0.444 & 0.669 & 0.091 & 5.078 \\
\hline \multirow[t]{4}{*}{ Healthcare } & 2 & 0.931 & -1.112 & -0.552 & 1.029 & 0.146 & 2.051 \\
\hline & 4 & 0.890 & -0.950 & -0.501 & 1.018 & 0.080 & $2.690^{* *}$ \\
\hline & 8 & 0.741 & -1.411 & -0.793 & 0.531 & -0.528 & $3.434^{\star *}$ \\
\hline & 16 & 0.546 & -1.661 & -1.017 & 0.663 & -0.499 & $4.199^{\star *}$ \\
\hline \multirow[t]{4}{*}{ Lodging/resort } & 2 & 1.160 & $2.577^{\star * *}$ & $2.098^{* *}$ & 1.106 & 1.480 & $2.051 * *$ \\
\hline & 4 & 1.285 & $2.454^{\star *}$ & $2.006^{* *}$ & $2.086^{\star *}$ & $2.025^{\star *}$ & $3.155^{\star * *}$ \\
\hline & 8 & 1.555 & $3.020^{* * *}$ & $2.453^{\star *}$ & $2.131^{* *}$ & $2.149^{\star *}$ & $2.951^{* * *}$ \\
\hline & 16 & 1.964 & $3.524^{* * *}$ & $2.885^{\star * *}$ & $2.202^{* *}$ & $2.221^{* *}$ & $2.703^{* * *}$ \\
\hline \multirow[t]{4}{*}{ Self-storage } & 2 & 0.769 & $3.715^{* * *}$ & $-2.344^{* *}$ & -1.323 & $-2.135^{\star *}$ & 0.559 \\
\hline & 4 & 0.690 & $2.663^{* * *}$ & -1.734 & -0.866 & -1.700 & 1.594 \\
\hline & 8 & 0.753 & -1.346 & -0.875 & 0.379 & -0.528 & 2.951 \\
\hline & 16 & 0.902 & -0.359 & -0.238 & 1.543 & 0.448 & 4.676 \\
\hline Timberland & 2 & 0.875 & -0.924 & -0.951 & -0.899 & -1.429 & 0.405 \\
\hline & 4 & 1.040 & 0.159 & 0.165 & 0.020 & -0.406 & 0.577 \\
\hline & 8 & 0.986 & -0.035 & -0.038 & -0.441 & -0.724 & 0.501 \\
\hline & 16 & 0.912 & -0.148 & -0.163 & -0.770 & -0.857 & 0.230 \\
\hline Infrastructure & 2 & 0.818 & -1.193 & -0.948 & -1.693 & -1.577 & $-2.287^{\star *}$ \\
\hline & 4 & 0.808 & -0.674 & -0.578 & -1.228 & -1.184 & -1.304 \\
\hline & 8 & 0.700 & -0.664 & -0.609 & -1.171 & -1.164 & -0.748 \\
\hline & 16 & 0.428 & -0.853 & -0.852 & -1.231 & -1.232 & -0.736 \\
\hline
\end{tabular}

$\mathrm{VR}(\mathrm{k})$ is the variance ratio estimate. $\mathrm{Z}^{\star}(\mathrm{k})$ is the test statistic with heteroskedastic robust standard error estimates and $\mathrm{Z}(\mathrm{k})$ is the test statistic with standard error estimates with homoskedastic assumption. Probability approximation using studentized maximum modulus (SMM). ${ }^{* *}$, ${ }^{* *}$ significant at the $5 \%$ and $1 \%$ levels, respectively. 
of the number of constituents. Subsectors with less constituents are more prone to idiosyncratic risks (companyspecific). Second, they differ in terms of their market capitalization. On average, smaller cap stocks are found to be less informational efficient when compared to larger cap stocks since smaller-cap are followed by a smaller number of analysts and usually have less media coverage and therefore less information to investors. Third, they differ in their dividend yields. Since some investors are attracted towards such style (high dividend yield) this could create a clientele effect and alter the demand of a particular subsector. Fourth, the underlying drivers are different when comparing the subsectors in terms of their reaction to certain economic conditions and demographics. Sectorspecific factors such as length of lease could also cause differences. Shorter-term leases such as lodging are quickly affected by recession and lower discretionary spending. Fifth, differences in the level of leverage (debt) used could also affect results.

\section{Performance of trading strategies}

This research mimics the testing completed in Schindler, Rottke, and Fuss (2010) and Schindler (2011) to examine the possibility of capitalizing on the inefficiencies of some REIT subsectors. This study works to measure the magnitude of market inefficiency and potential mispricing to see if mispricing may be in excess of transaction costs. Practitioners are expected to implement a trading system which applies technical analysis trading rules such as moving average indicators. Therefore, trading rules of moving averages for REIT subsectors are applied and compared to a buy-and-hold strategy. Markets are considered inefficient if past information using moving averages generates excess returns. According to Brock, Lakonishok, and Lebaron (1992), a buying (selling) signal occurs when the shorter moving average is above (below) the longer moving average. Similarly, if the index breaks its moving average from the bottom going up, it is considered a buy signal. In contrast, if the index breaks its moving average from top going down, then it is believed to be a sell signal. See Figure 2 below.
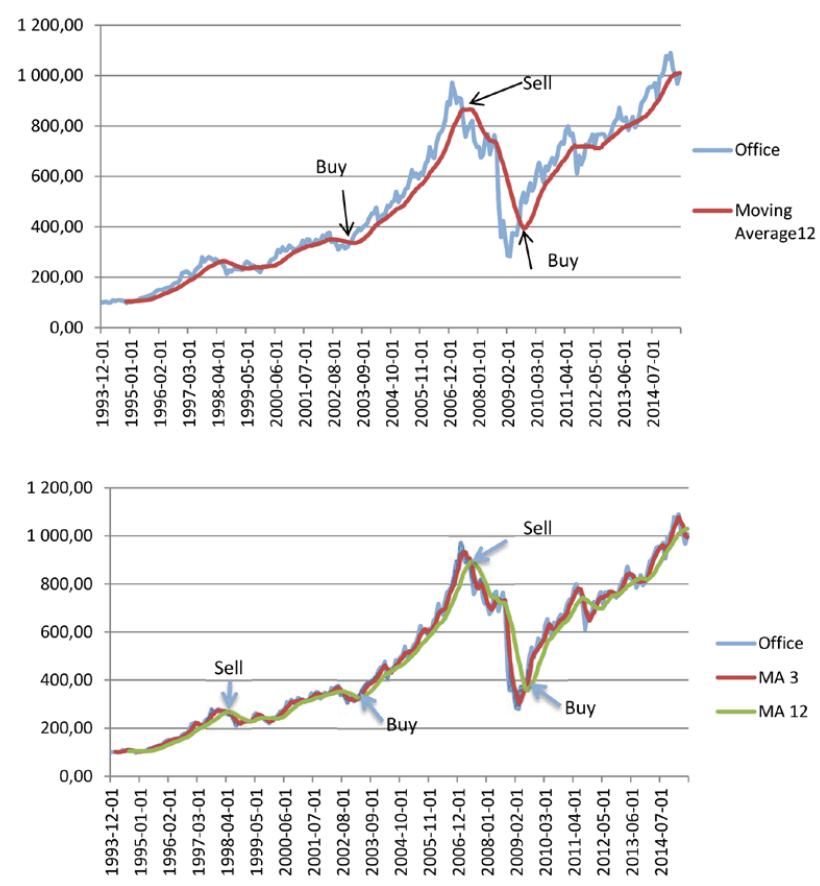

Figure 2. Illustration of the technical trading rule of 12 months moving average with the buy and sell signals

Table 4. Annual returns from Buy-and-hold strategy compared to technical trading strategy based on moving averages (MA)

\begin{tabular}{|c|c|c|c|c|c|c|c|c|}
\hline \multirow{2}{*}{ Index } & \multirow{2}{*}{$\begin{array}{l}\text { Buy\& } \\
\text { hold }\end{array}$} & \multicolumn{4}{|c|}{$\begin{array}{l}\text { Closing vs. moving average } \\
\text { with transactions costs }\end{array}$} & \multicolumn{3}{|c|}{$\begin{array}{l}\text { MA3 vs. moving average } \\
\text { with transactions costs }\end{array}$} \\
\hline & & 3 month & 6 month & 9 month & 12 month & 6 month & 9 month & 12 month \\
\hline Office & $11.12 \%$ & $7.84 \%$ & $10.49 \%$ & $13.07 \%$ & $10.84 \%$ & $13.80 \%$ & $11.73 \%$ & $8.81 \%$ \\
\hline Industrial & $8.29 \%$ & $8.16 \%$ & $9.20 \%$ & $9.33 \%$ & $8.34 \%$ & $7.15 \%$ & $9.76 \%$ & $7.60 \%$ \\
\hline Mixed & $8.83 \%$ & $3.41 \%$ & $3.14 \%$ & $2.77 \%$ & $2.47 \%$ & $4.17 \%$ & $3.94 \%$ & $2.44 \%$ \\
\hline Shopping centers & $9.79 \%$ & $7.13 \%$ & $7.57 \%$ & $9.96 \%$ & $9.32 \%$ & $9.52 \%$ & $12.29 \%$ & $9.82 \%$ \\
\hline Regional malls & $13.02 \%$ & $12.04 \%$ & $12.40 \%$ & $14.72 \%$ & $14.28 \%$ & $11.23 \%$ & $14.70 \%$ & $14.74 \%$ \\
\hline Free standing & $12.55 \%$ & $8.88 \%$ & $8.02 \%$ & $9.64 \%$ & $8.93 \%$ & $6.28 \%$ & $8.01 \%$ & $7.53 \%$ \\
\hline Apartments & $11.93 \%$ & $5.05 \%$ & $9.77 \%$ & $8.91 \%$ & $8.76 \%$ & $11.81 \%$ & $12.01 \%$ & $10.59 \%$ \\
\hline Manuf. homes & $10.64 \%$ & $3.86 \%$ & $6.44 \%$ & $7.36 \%$ & $6.77 \%$ & $5.46 \%$ & $6.82 \%$ & $5.22 \%$ \\
\hline Diversified & $8.72 \%$ & $6.70 \%$ & $7.39 \%$ & $9.78 \%$ & $9.36 \%$ & $9.47 \%$ & $9.40 \%$ & $7.13 \%$ \\
\hline Healthcare & $12.36 \%$ & $8.89 \%$ & $10.53 \%$ & $12.67 \%$ & $10.17 \%$ & $9.84 \%$ & $10.57 \%$ & $7.92 \%$ \\
\hline Lodging/resort & $5.57 \%$ & $9.70 \%$ & $10.39 \%$ & $12.94 \%$ & $12.07 \%$ & $10.55 \%$ & $11.70 \%$ & $8.75 \%$ \\
\hline Self-storage & $16.36 \%$ & $9.53 \%$ & $12.26 \%$ & $13.95 \%$ & $12.04 \%$ & $11.26 \%$ & $14.86 \%$ & $10.76 \%$ \\
\hline Timberland & $10.67 \%$ & $5.65 \%$ & $4.64 \%$ & $3.72 \%$ & $5.25 \%$ & $5.47 \%$ & $5.37 \%$ & $6.33 \%$ \\
\hline Infrastructure & $14.57 \%$ & $11.74 \%$ & $5.49 \%$ & $5.49 \%$ & $5.16 \%$ & $5.79 \%$ & $5.77 \%$ & $5.79 \%$ \\
\hline
\end{tabular}


Table 5. Sharpe ratio statistics for buy-and-hold and trading strategy portfolios

\begin{tabular}{|l|c|c|c|c|c|c|c|c|}
\hline & $\begin{array}{c}\text { Buy\& } \\
\text { Hold }\end{array}$ & MA 3 & MA 6 & MA 9 & MA 12 & MA 3/6 & MA 3/9 & MA 3/12 \\
\hline Office & 0.366 & 0.312 & 0.378 & 0.517 & 0.446 & $0.609 *$ & 0.414 & 0.298 \\
\hline Industrial & 0.250 & 0.423 & 0.447 & 0.388 & 0.376 & 0.235 & 0.388 & 0.282 \\
\hline Mixed & 0.310 & 0.062 & 0.050 & 0.022 & 0.006 & 0.102 & 0.098 & 0.003 \\
\hline Shopping centers & 0.343 & 0.253 & 0.263 & 0.391 & 0.341 & 0.395 & 0.583 * & 0.394 \\
\hline Regional malls & 0.380 & 0.542 & 0.535 & $0.618^{\star}$ & 0.613 * & 0.395 & 0.545 & 0.630 * \\
\hline Free standing & 0.594 & 0.452 & 0.356 & 0.440 & 0.373 & 0.200 & 0.276 & 0.251 \\
\hline Apartments & 0.455 & 0.133 & 0.347 & 0.303 & 0.305 & 0.458 & 0.480 & 0.447 \\
\hline Manuf. homes & 0.461 & 0.095 & 0.228 & 0.315 & 0.262 & 0.153 & 0.270 & 0.164 \\
\hline Diversified & 0.303 & 0.280 & 0.272 & 0.396 & 0.385 & 0.357 & 0.387 & 0.270 \\
\hline Healthcare & 0.455 & 0.359 & 0.415 & 0.564 & 0.437 & 0.353 & 0.401 & 0.274 \\
\hline Lodging/resort & 0.095 & $0.432 *$ & $0.357 *$ & $0.518 *$ & $0.452 *$ & $0.370 *$ & 0.427 & $0.270 *$ \\
\hline Self-storage & 0.724 & 0.457 & 0.545 & $0.690 *$ & 0.542 & 0.419 & 0.643 & 0.424 \\
\hline Timberland & 0.646 & 0.375 & 0.404 & 0.251 & 0.374 & 0.291 & 0.405 & 0.482 \\
\hline Infrastructure & 1.018 & 1.130 & 0.544 & 0.544 & 0.500 & 0.584 & 0.572 & 0.575 \\
\hline
\end{tabular}

As suggested in Schindler et al. (2010), we follow the steps of Gibbons et al. (1989) in calculating W statistic, W - modified to test the null hypothesis that: Sharpe Ratio $_{i}=$ Sharpe Ratio $_{j}{ }^{*}$ indicates that the trading strategy is superior to the buy-and-hold strategy with $5 \%$ significance.

The study assumes that the transaction costs are $0.1 \%$ per transaction ${ }^{4}$, similar to Schindler, Rottke, and Fuss (2010), and that short selling is prohibited. Table 4 shows returns per annum of buy-and hold versus trading rules strategies. It should be noted that the returns of the buy and hold strategy always outperform the moving average rules for free-standing, manufactured homes, self-storage, mixed, timberland, and infrastructure subsectors. Few trading rules outperform the buy and hold strategy in absolute terms in the other subsectors. In the lodging/resort subsector, the moving average strategy is always superior.

The Sharpe ratios of both strategies are compared to control for risks, as shown in Table 5. The Sharpe ratio of some trading strategies is larger than that of the buy and hold strategy; however, it is not statistically significant in most subsectors, at $5 \%$, when using the procedure of Gibbons, Ross, and Shanken (1989). It is clear that the buy and hold strategy is superior to the technical trading strategies in most of the subsectors, as shown in Table 5. It seems that investors can apply moving averages in lodging/resort and regional malls subsectors. This finding could be interpreted as investors not being able to earn abnormal returns when using historical REIT information. The risk adjusted performance of buy and hold is hard to beat when using the moving average technical trading rules. This is consistent with the results found in Schindler et al. (2010), indicating that the buy and hold strategy outperforms moving average rules in the US when using EPRA NAREIT during the period 1990-2006.

\footnotetext{
4 Transaction costs of $0.1 \%$ per transaction could be relatively conservative. A robustness check with higher transaction costs of $0.3 \%$ was also considered. Main conclusions remain valid. Results are not included due to space limitation but are available from the authors upon request.
}

\section{Robustness check}

Since REITs experienced several events during the 21 years examined, a Quandt-Andrews unknown structural breakpoint test was performed. February 2007 has the maximum LR and Wald F-statistic, this is close to the financial crisis. Therefore, the entire sample is split into subsamples, before and after February 2007, and the above mentioned tests are rerun on both periods, as shown in Table 6. Since the data availability of mixed, timber and infrastructure is pulled from 1996, 2011, and 2012, their break points are different. The break points for mixed, timber, and infrastructure are February 2007, October 2011, and December 2014 , respectively. It should be noted that when the nonparametric runs test is redone after the breakpoint, it fails to reject the null hypothesis of randomness, as shown in Table 6. This indicates that all REIT subsectors are weakform efficient after the above mentioned break points. This could be interpreted as support of REITs, recently, being more informationally efficient.

In addition, the performance of trading rules of moving averages for REIT subsectors is reexamined and compared to a buy-and-hold strategy during the post structural break subsample period, as shown in Table 7. The returns of the buy and hold strategy, in this study, always outperform the moving average rules in free standing, manufactured homes, healthcare and timberland. During the period 2007-2015, the performance of moving average strategies outperforms naïve buy and hold strategies in office, industrial, regional malls and lodging/resort subsectors. Applying moving averages in lodging/resort and regional malls subsectors seems to be robust.

To compare the Sharpe ratios of different subsectors, we use the method of Opdyke (2007) which improves the 
Table 6. Non parametric runs test results with structural break

Panel A: subsample period from January 1994 to February 2007

\begin{tabular}{|l|c|c|c|c|}
\hline & $\mathrm{M}$ & $\mathrm{E}(\mathrm{M})$ & $\sigma(\mathrm{M})$ & $\mathrm{Z}$ \\
\hline Office & 70 & 80 & 6.265 & -1.596 \\
\hline Industrial & 63 & 80 & 6.265 & $-2.713^{\star *}$ \\
\hline Mixed & 72 & 68 & 5.766 & 0.694 \\
\hline Shopping centers & 59 & 80 & 6.265 & $-3.352^{\star *}$ \\
\hline Regional malls & 71 & 80 & 6.265 & -1.437 \\
\hline Free standing & 74 & 80 & 6.265 & -0.958 \\
\hline Apartments & 80 & 75 & 5.861 & 0.864 \\
\hline Manufactured homes & 76 & 80 & 6.265 & -0.638 \\
\hline Diversified & 59 & 80 & 6.265 & $-3.352^{\star *}$ \\
\hline Healthcare & 66 & 80 & 6.265 & $-2.234^{\star *}$ \\
\hline Lodging/resort & 61 & 80 & 6.265 & $-3.033^{\star *}$ \\
\hline Self-storage & 72 & 80 & 6.265 & -1.277 \\
\hline Timberland & 5 & 6 & 1.5 & -0.667 \\
\hline Infrastructure & 24 & 19 & 2.985 & 1.690 \\
\hline
\end{tabular}

Panel B: subsample period from to February 2007 to July 2015

\begin{tabular}{|l|c|c|c|c|}
\hline & $\mathrm{M}$ & $\mathrm{E}(\mathrm{M})$ & $\sigma(\mathrm{M})$ & $\mathrm{Z}$ \\
\hline Office & 54 & 51.5 & 5 & 0.5 \\
\hline Industrial & 54 & 51.5 & 5 & 0.5 \\
\hline Mixed & 50 & 51.5 & 5 & -0.3 \\
\hline Shopping centers & 52 & 51.5 & 5 & 0.1 \\
\hline Regional malls & 50 & 51.5 & 5 & -0.3 \\
\hline Free standing & 47 & 51.5 & 5 & -0.9 \\
\hline Apartments & 56 & 51.5 & 5 & 0.9 \\
\hline Manufactured homes & 50 & 51.5 & 5 & -0.3 \\
\hline Diversified & 54 & 51.5 & 5 & 0.5 \\
\hline Healthcare & 48 & 51.5 & 5 & -0.7 \\
\hline Lodging/resort & 52 & 51.5 & 5 & 0.1 \\
\hline Self-storage & 54 & 51.5 & 5 & 0.5 \\
\hline Timberland & 21 & 23.5 & 3.316 & -0.754 \\
\hline Infrastructure & 5 & 4.5 & 1.225 & 0.408 \\
\hline
\end{tabular}

$M$ is the actual number of runs, $E(M)$ is the expected number of runs, $\sigma(M)$ is the standard errors of runs, ${ }^{* *}$ indicates significance at the $5 \%$ level. In panel A, subsample of timberland is Dec 2010 to Oct 2011 while subsample of infrastructure is Dec 2011 to Dec 2014. In panel B, subsample of timberland is Oct 2011 to Jul 2015 while subsample of infrastructure is Dec 2014 to Jul 2015.

Table 7. Annual returns from Buy-and-hold strategy compared to technical trading strategy based on moving averages (MA) for subsample period from to February 2007 to July 2015

\begin{tabular}{|l|c|c|c|c|c|c|c|c|}
\hline \multirow{2}{*}{\multicolumn{1}{c}{ Index }} & \multirow{2}{*}{$\begin{array}{l}\text { Buy\& } \\
\text { Hold }\end{array}$} & \multicolumn{3}{c|}{$\begin{array}{c}\text { Closing vs. moving average } \\
\text { with transactions costs }\end{array}$} & \multicolumn{3}{c|}{$\begin{array}{c}\text { MA3 vs. moving average } \\
\text { with transactions costs }\end{array}$} \\
\cline { 3 - 9 } & & 3 month & 6 month & 9 month & 12 month & 6 month & 9 month & 12 month \\
\hline Office & $0.37 \%$ & $-0.22 \%$ & $4.58 \%$ & $7.71 \%$ & $4.44 \%$ & $11.68 \%$ & $3.03 \%$ & $0.21 \%$ \\
\hline Industrial & $-6.14 \%$ & $3.52 \%$ & $6.99 \%$ & $4.4 \%$ & $0.57 \%$ & $1.28 \%$ & $1.62 \%$ & $-3.03 \%$ \\
\hline Mixed & $-1.26 \%$ & $-5.48 \%$ & $0.16 \%$ & $-2.50 \%$ & $-2.59 \%$ & $-0.59 \%$ & $-0.22 \%$ & $-2.93 \%$ \\
\hline Shopping centers & $-0.88 \%$ & $-2.71 \%$ & $-0.01 \%$ & $2.5 \%$ & $0.80 \%$ & $8.67 \%$ & $8.00 \%$ & $4.30 \%$ \\
\hline Regional malls & $2.47 \%$ & $12.09 \%$ & $13.28 \%$ & $13.06 \%$ & $9.75 \%$ & $10.95 \%$ & $13.85 \%$ & $13.50 \%$ \\
\hline Free standing & $8.16 \%$ & $4.30 \%$ & $4.39 \%$ & $6.54 \%$ & $4.46 \%$ & $0.63 \%$ & $0.23 \%$ & $0.17 \%$ \\
\hline Apartments & $6.65 \%$ & $-0.79 \%$ & $6.88 \%$ & $6.03 \%$ & $3.23 \%$ & $8.71 \%$ & $9.61 \%$ & $5.46 \%$ \\
\hline Manuf. homes & $11.43 \%$ & $1.50 \%$ & $4.87 \%$ & $10.32 \%$ & $8.88 \%$ & $4.24 \%$ & $9.71 \%$ & $8.67 \%$ \\
\hline Diversified & $1.78 \%$ & $0.88 \%$ & $2.35 \%$ & $3.82 \%$ & $2.80 \%$ & $7.15 \%$ & $4.43 \%$ & $0.42 \%$ \\
\hline Healthcare & $8.18 \%$ & $3.20 \%$ & $7.15 \%$ & $8.80 \%$ & $6.13 \%$ & $4.01 \%$ & $6.74 \%$ & $1.13 \%$ \\
\hline Lodging/resort & $0.45 \%$ & $1.65 \%$ & $7.45 \%$ & $9.96 \%$ & $12.37 \%$ & $9.71 \%$ & $12.34 \%$ & $8.41 \%$ \\
\hline Self-storage & $12.01 \%$ & $4.30 \%$ & $9.85 \%$ & $13.57 \%$ & $14.59 \%$ & $9.21 \%$ & $12.08 \%$ & $13.03 \%$ \\
\hline Timberland & $12.02 \%$ & $7.44 \%$ & $6.07 \%$ & $4.87 \%$ & $6.72 \%$ & $7.04 \%$ & $6.75 \%$ & $7.94 \%$ \\
\hline Infrastructure & $-2.84 \%$ & $-6.24 \%$ & NA & NA & NA & NA & NA & NA \\
\hline
\end{tabular}

Note: subsample of timberland is Oct 2011 to Jul 2015 and subsample of infrastructure is Dec 2014 to Jul 2015. All other subsectors are from Feb 2007 to Jul 2015.

work of Jobson and Korkie $(1981)^{5}$. Results presented in Table 8 show based on risk-adjusted performance (Sharpe ratio), the best subsector is self-storage while the worst subsector is lodging/resort. We note that self-storage has a Sharpe ratio that is larger with statistical significance than subsectors of office, industrial, mixed, shopping centers,

\footnotetext{
5 We are grateful for the anonymous referee for pointing this out which improves the paper.
}

diversified and lodging/resort. Moreover, we find that lodging/resort is inferior to regional malls, free-standing, apartments and self-storage.

We examine the long-range dependence through fractional integration (Granger \& Joyeux, 1980) ${ }^{6}$. When the autocorrelations are persistent and decay slowly, the

\footnotetext{
6 We thank the anonymous referee for this great suggestion and addition to the paper.
} 
Table 8. Sharpe ratio comparison of different REIT subsectors (row versus column)

\begin{tabular}{|c|c|c|c|c|c|c|c|c|c|c|c|c|c|c|}
\hline & $\underset{\mathscr{C}}{\ddot{\Xi}}$ & 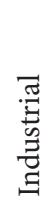 & $\begin{array}{l}\vec{\otimes} \\
\stackrel{x}{\Sigma}\end{array}$ & 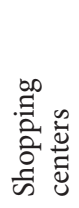 & 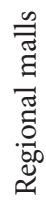 & 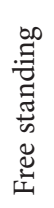 & 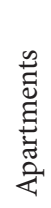 & 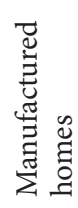 & 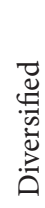 & 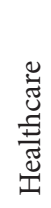 & 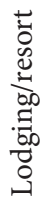 & 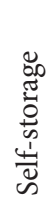 & 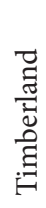 & 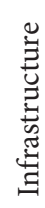 \\
\hline Office & - & & & & & & & & & & & & & \\
\hline Industrial & & - & & & & & & & & & & & & \\
\hline Mixed & & & - & & & & & & & & & & & \\
\hline Shopping centers & & & & - & & & & & & & & & & \\
\hline Regional malls & & & & & - & & & & & & * & & & \\
\hline Free standing & & & & & & - & & & & & * & & & \\
\hline Apartments & & & & & & & - & & & & * & & & \\
\hline Manufactured homes & & & & & & & & - & & & & & & \\
\hline Diversified & & & & & & & & & - & & & & & \\
\hline Healthcare & & & & & & & & & & - & & & & \\
\hline Lodging/resort & & & & & & & & & & & - & & & \\
\hline Self-storage & * & * & * & * & & & & & * & & * & - & & \\
\hline Timberland & & & & & & & & & & & & & - & \\
\hline Infrastructure & & & & & & & & & & & & & & - \\
\hline
\end{tabular}

We compare the Sharpe ratio of the subsector in row with the Sharpe ratio of subsector in the column. We use the method of Opdyke (2007) which improves the work of Jobson and Korkie (1981). When comparing a subsector with mixed, timberland and infrastructure, we use a similar time periods because of data availability. ${ }^{*}$ indicates that the Sharpe ratio of subsector (row) is larger with statistical significance at $10 \%$ level than the Sharpe ratio of subsector (column). A blank box indicates that Sharpe ratios of subsector (row) is not larger with statistical significance than the Sharpe ratio of subsector (column).

Table 9. Long memory in REITs subsectors using ARFIMA (1,d,1)

\begin{tabular}{|c|c|c|c|}
\hline & $\varnothing_{1}$ & $\Theta_{1}$ & $\mathrm{~d}$ \\
\hline Office & $-0.779(-6.309) *$ & $0.874(8.627)^{*}$ & $0.003(0.103)$ \\
\hline Industrial & $-0.556(-9.551)^{*}$ & $0.813(17.837)^{\star}$ & $-0.085(-3.248)^{*}$ \\
\hline Mixed & $-0.441(-2.057)^{*}$ & $0.616(3.199)^{*}$ & $-0.103(-2.365)$ * \\
\hline Shopping centers & $-0.379(-2.585)^{*}$ & $0.585(4.077)^{\star}$ & $-0.084(-2.551)$ * \\
\hline Regional malls & $-0.284(1.025)$ & $0.443(1.628)$ & $0.011(0.336)$ \\
\hline Free standing & $-0.769(-4.253)$ * & $0.843(5.264)^{*}$ & $-0.133(-3.154)$ * \\
\hline Apartments & $0.922(14.821)^{*}$ & $-0.109(-0.744)$ & $-0.847(-4.350)$ * \\
\hline Manufactured homes & $0.481(1.131)$ & $-0.557(-1.118)$ & $-0.008(-0.051)$ \\
\hline Diversified & $-0.363(-2.759) *$ & $0.652(5.571)^{*}$ & $-0.089(-2.756)$ * \\
\hline Healthcare & $-0.722(-5.663)^{*}$ & $0.840(7.903)$ * & $-0.091(-2.057) *$ \\
\hline Lodging/resort & $-0.384(-2.819)^{\star}$ & $0.689(5.544)^{*}$ & $-0.026(-0.656)$ \\
\hline Self-storage & $-0.840(-5.618)^{\star}$ & $0.897(7.305)^{*}$ & $-0.093(-2.076) *$ \\
\hline Timberland & $0.797(0.493)$ & $-0.206(-0.096)$ & $-0.663(-0.172)$ \\
\hline Infrastructure & $0.783(0.697)$ & $-0.039(-0.038)$ & $-1.040(-0.468)$ \\
\hline
\end{tabular}

ARFIMA $(1, d, 1)$ estimation results using maximum likelihood where $\emptyset_{1}$ is the $\operatorname{AR}(1)$ coefficient, $\Theta_{1}$ is the $\operatorname{MA}(1)$ coefficient, $d$ is the long memory coefficient, t-statistics are in parenthesis. ${ }^{*}$ indicates significance at the $5 \%$ level.

stationary process has long memory. Long memory hypothesis and whether shocks persist through long time periods have been tested and documented to exist in REITs returns and volatilities of some international markets while weak evidence was provided in other cases (e.g. Assaf, 2015; Cotter \& Stevenson, 2008; Liow, 2009; Pavlova, Cho, Parhizgari, \& Hardin III, 2014; Zhou, 2011). Using an ARFIMA (1,d,1) model, we revisit this question using
REIT subsectors instead of general REITs. Our findings as shown in Table 9 indicate that the fractional integration parameter (d) is significant in REIT subsectors of industrial, mixed, shopping centers, free standing, apartments, diversified, healthcare and self-storage. There is strong evidence of long-memory in these subsectors where shocks persist over long time periods. However, we do not find any evidence of long memory in subsectors of office, regional 
Table 10. Unit root tests results with the possibility of structural breaks using Vogelsang and Perron (1998)

\begin{tabular}{|c|c|c|c|c|}
\hline & $\begin{array}{l}\text { ADF t-stat } \\
\text { using first difference }\end{array}$ & $\begin{array}{l}\text { Break date using } 1^{\text {st }} \\
\text { difference }\end{array}$ & ADF t-stat using level & Break date using level \\
\hline Office & $-17.159^{*}$ & Oct 2008 & -4.836 & Aug 2008 \\
\hline Industrial & $-15.961 *$ & Oct 2008 & $-5.742 *$ & May 2008 \\
\hline Mixed & $-16.499 *$ & Oct 2008 & -4.950 & Sep 2008 \\
\hline Shopping centers & $-16.020^{*}$ & Feb 2009 & -5.093 & Sep 2008 \\
\hline Regional malls & $-16.338^{*}$ & Oct 2008 & -4.653 & May 2008 \\
\hline Free standing & $-17.880 *$ & Nov 2008 & -4.181 & Oct 2007 \\
\hline Apartments & $-19.143^{\star}$ & Feb 2009 & -4.089 & Sep 2008 \\
\hline Manufactured homes & $-18.371 *$ & Aug 2013 & -4.583 & Sep 2008 \\
\hline Diversified & $-13.677^{\star}$ & Feb 2009 & -4.319 & Jul 2008 \\
\hline Healthcare & $-18.545^{\star}$ & Nov 2008 & -4.377 & Sep 2008 \\
\hline Lodging/resort & $-14.451^{\star}$ & Oct 2008 & -3.615 & May 2008 \\
\hline Self-storage & $-20.430 *$ & Nov 2008 & -4.768 & Sep 2008 \\
\hline Timberland & $-9.244^{*}$ & May 2013 & -3.523 & May 2012 \\
\hline Infrastructure & $-8.499^{*}$ & Oct 2013 & -3.765 & April 2013 \\
\hline
\end{tabular}

We use a trend and intercept in our specification. The break point selection is based on minimizing Dickey-Fuller t-statistic. Lag length is based on SIC. * indicates significance at $5 \%$ level.

malls, manufactured homes, lodging/resort, timberland and infrastructure which supports the efficient market hypothesis. Similar to prior findings, differences exist among subsectors which reconfirm the notion that they deserve to be evaluated separately. Furthermore, we run unit root tests with the possibility of a structural break using the Vogelsang and Perron (1998) method. Findings from Table 10 show that all subsectors are stationary after taking the first difference. While breakpoints differ between subsectors, they coincide with the global financial crisis of 2008.

\section{Conclusion}

The purpose of this study is to examine the random walk behavior of REIT subsectors. The sample period spans 21-years, from January 1994 to July 2015. Using variance ratio tests, the results from this research suggest that the lodging/resorts and self-storage subsectors do not follow a random walk. The findings are confirmed using runs tests which reject the null hypothesis of randomness for lodging/resorts and self-storage. Technical equity traders could potentially find opportunities for profitable trading strategies based on historical pricing information if the market is not weak form efficient. However, it must be recognized that abnormal returns could erode from transaction costs. Technical trading rules seem to be superior than buy and hold in the lodging/resort subsector even after accounting for transaction costs and adjusting for risk, as shown by better Sharpe ratios. However, moving average trend indicators fail to outperform the buy and hold strategy after controlling for risk in most other REIT subsectors.

Furthermore, this study shows mixed results for the random walk in other REIT subsectors (i.e., shopping centers, health care, diversified and infrastructure). The random walk is sensitive to the method, number of lags, and assumptions in a study. The evidence in this study supports the view that some subsectors are more informationally efficient than other subsectors. The arguments put forth by Block (2012), which argued that REIT subsectors have different characteristics, risks, cycles, and behave differently from one another and therefore deserve to be evaluated separately, are supported. REIT subsectors might have different degrees of informational efficiency because of differences in institutional ownership, frequency and volume of trading (liquidity), level of information (analyst and media coverage), varying level of valuation difficulty, and differences in size or leverage.

\section{References}

Aguilar, M., Boudry, W., \& Connolly, R. (2015). Cross-sectional dynamics of REIT market efficiency. Working paper presented at NAREIT-AREUEA Real Estate Research Conference, New York.

Akinsomi, O., Aye, G. C., Babalos, V., Economou, F., \& Gupta, R. (2016). Real estate returns predictability revisited: novel evidence from the US REITs market. Empirical Economics, 51(3), 1165-1190. https://doi.org/10.1007/s00181-015-1037-5

Assaf, A. (2015). Long memory and level shifts in REITs returns and volatility. International Review of Financial Analysis, 42, 172-182. https://doi.org/10.1016/j.irfa.2015.06.004

Bianchi, D., Guidolin, M., \& Ravazollo, F. (2013). What makes residential different from non-residential REITs? Evidence from multi-factor asset pricing models. Working paper presented at ASSA conference, San Diego.

Block, R. (2012). Investing in REITs (4 $4^{\text {th }}$ ed.). New Jersey: Wiley. https://doi.org/10.1002/9781119202325

Brock, W., Lakonishok, J., \& Lebaron, B. (1992). Simple technical trading rules and the stochastic properties of stock returns. Journal of Finance, 47(5), 1731-1764. https://doi.org/10.1111/j.1540-6261.1992.tb04681.x

Chong, J., Krystalogianni, A., \& Stevenson, S. (2012). Dynamic correlations between REIT subsectors and the implications 
for diversification. Applied Financial Economics, 22, 10891109. https://doi.org/10.1080/09603107.2011.639735

Chui, A. C., Titman, S., \& Wei, K. J. (2003). Intra-industry momentum: the case of REITs. Journal of Financial Markets, 6(3), 363-387. https://doi.org/10.1016/S1386-4181(03)00002-8

Cotter, J., \& Stevenson, S. (2008). Modeling long memory in REITs. Real Estate Economics, 36(3), 533-554. https://doi.org/10.1111/j.1540-6229.2008.00221.x

Feng, Z., Price, S. M., \& Sirmans, C. F. (2014). The relation between momentum and drift: industry-level evidence from equity Real Estate Investment Trusts (REITs). Journal of Real Estate Research, 36(3), 383-407.

Gibbons, M. R., Ross, S. A., \& Shanken, J. (1989). A test of the efficiency of a given portfolio. Econometrica, 57(5), 1121-1152. https://doi.org/10.2307/1913625

Goebel, P. R., Harrison, D. M., Mercer, J. M., \& Whitby, R. J. (2013). REIT momentum and characteristic-related REIT returns. Journal of Real Estate Finance and Economics, 47(3), 564-581. https://doi.org/10.1007/s11146-012-9371-2

Granger, C. W., \& Joyeux, R. (1980). An introduction to longmemory time series models and fractional differencing. Journal of Time Series Analysis, 1(1), 15-29.

https://doi.org/10.1111/j.1467-9892.1980.tb00297.x

Hao, Y., Chu, H. H., Ko, K. C., \& Lin, L. (2016). Momentum strategies and investor sentiment in the REIT market. International Review of Finance, 16(1), 41-71. https://doi.org/10.1111/irfi.12060

Ho, K. H. D., \& Tay, S. J. (2016). REIT market efficiency through a binomial option pricing tree approach. Journal of Property Investment \& Finance, 34(5), 496-520.

https://doi.org/10.1108/JPIF-01-2016-0004

Hoesli, M., \& Oikarinen, E. (2012). Are REITs real estate? Evidence from international sector level data. Journal of International Money and Finance, 31(7), 1823-1850.

https://doi.org/10.1016/j.jimonfin.2012.05.017

Hui, E. C. M., Wright, J. A., \& Yam, S. C. P. (2014). Calendar effects and real estate securities. Journal of Real Estate Finance and Economics, 49(1), 91-115.

https://doi.org/10.1007/s11146-012-9398-4

Hui, E. C. M., \& Yam, S. C. P. (2014). Can we beat the "buyand-hold" strategy? Analysis on European and American securitized real estate indices. International Journal of Strategic Property Management, 18(1), 28-37.

https://doi.org/10.3846/1648715X.2013.862190

Hung, S. Y. K., \& Glascock, J. L. (2008). Momentum profitability and market trend: evidence from REITs. Journal of Real Estate Finance and Economics, 37(1), 51-69.

https://doi.org/10.1007/s11146-007-9056-4

Jirasakuldech, B., \& Knight, J. (2005). Efficiency in the market for REITs: further evidence. Journal of Real Estate Portfolio Management, 11, 123-132.

Jobson, J. D., \& Korkie, B. M. (1981). Performance hypothesis testing with the Sharpe and Treynor measures. Journal of Finance, 36(4), 889-908. https://doi.org/10.1111/j.1540-6261.1981.tb04891.x

Kleiman, R., Payne, J., \& Sahu, A. (2002). Random walks and market efficiency: evidence from international real estate markets. Journal of Real Estate Research, 24, 279-297.

Kuhle, J., \& Alvayay, J. (2000). The efficiency of equity REIT prices. Journal of Real Estate Portfolio Management, 6, 349-354.

Lee, M. T., Lee, M. L., Chiu, B. H., \& Lee, C. L. (2014). Do lunar phases affect US REIT returns?. Investment Analysts Journal, 43(79), 67-78.

Lee, M., \& Chiang, K. (2004). Substitutability between equity REITs and mortgage REITs. Journal of Real Estate Research, 26, 95-113.
Liow, K. H. (2009). Long-term memory in volatility: some evidence from international securitized real estate markets. Journal of Real Estate Finance and Economics, 39(4), 415-438. https://doi.org/10.1007/s11146-008-9120-8

Lo, A., \& Mackinlay, A. (1988). Stock market prices do not follow random walks: evidence from a simple specification test. Review of Financial Studies, 1, 41-66. https://doi.org/10.1093/rfs/1.1.41

Lo, A., \& Mackinlay, A. (1989). The size and power variance ratio test in finite samples: a Monte Carlo investigation. Journal of Econometrics, 40, 203-238. https://doi.org/10.1016/0304-4076(89)90083-3

Mei, J., \& Gao, B. (1995). Price reversal, transaction costs, and arbitrage profits in the real estate securities market. Journal of Real Estate Finance and Economics, 11, 153-165. https://doi.org/10.1007/BF01098659

Oikarinen, E., Hoesli, M., \& Serrano, C. (2010). Response speeds of direct and securitized real estate to shocks in the fundamentals. Discussion Paper No. 60. Aboa Centre for Economics, Turku.

Opdyke, J. D. J. (2007). Comparing Sharpe ratios: so where are the p-values?. Journal of Asset Management, 8(5), 308-336. https://doi.org/10.1057/palgrave.jam.2250084

Pavlova, I., Cho, J. H., Parhizgari, A. M., \& Hardin III, W. G. (2014). Long memory in REIT volatility and changes in the unconditional mean: a modified FIGARCH approach. Journal of Property Research, 31(4), 315-332.

https://doi.org/10.1080/09599916.2013.877063

Payne, J. (2006). Further evidence on the transmission of shocks across REIT markets: an examination of REIT subsectors. Applied Financial Economics Letters, 2, 141-146. https://doi.org/10.1080/17446540500447629

Payne, J., \& Waters, G. (2007). Have equity REITs experienced periodically collapsing bubbles?. Journal of Real Estate Finance and Economics, 34, 207-224.

https://doi.org/10.1007/s11146-007-9007-0

Schindler, F. (2011). Market efficiency and return predictability in the emerging securitized real estate markets. Journal of Real Estate Literature, 19, 111-150.

Schindler, F., Rottke, N., \& Fuss, R. (2010). Testing the predictability and efficiency of securitized real estate markets. Journal of Real Estate Portfolio Management, 16, 171-191.

Stevenson, S. (2002). Momentum effects and mean reversion in real estate securities. Journal of Real Estate Research, 23, 47-64.

Su, J., Cheung, A., \& Roca, E. (2012). Are securitized real estate markets efficient? New international evidence based on an improved automatic portmanteau test. Economic Modelling, 29, 684-690. https://doi.org/10.1016/j.econmod.2012.01.015

Vogelsang, T. J., \& Perron, P. (1998). Additional tests for a unit root allowing for a break in the trend function at an unknown time. International Economic Review, 39(4), 1073-1100. https://doi.org/10.2307/2527353

Wright, J. (2000). Alternative variance ratio tests using ranks and signs. Journal of Business and Economics Statistics, 18, 1-9.

Yavas, A., \& Yildirim, Y. (2011). Price discovery in real estate markets: a dynamic analysis. Journal of Real Estate Finance and Economics, 42(1), 1-29. https://doi.org/10.1007/s11146-009-9172-4

Zhou, J. (2011). Long memory in REIT volatility revisited: genuine or spurious, and self-similar?, Journal of Property Research, 28(3), 213-232. https://doi.org/10.1080/09599916.2011.577903

Zhou, J., \& Lee, J. M. (2013). Adaptive market hypothesis: evidence from the REIT market. Applied Financial Economics, 23(21), 1649-1662. https://doi.org/10.1080/09603107.2013.844326 